Physical Disabilities: Education and Related Services, 2016, 35(1), 1-16. doi: 10.14434/pders.v35i1.20696

(C) Division for Physical, Health and Multiple Disabilities

PDERS

ISSN: 2372-451X

http://scholarworks.iu.edu/journals/index.php/pders/index

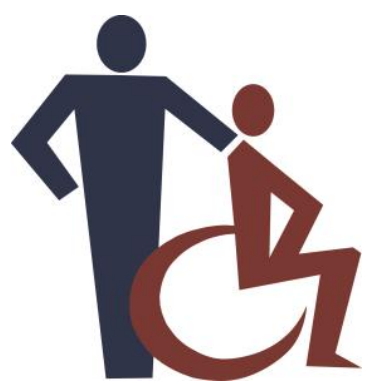

Article

\title{
COURT DECISIONS SPECIFIC TO PUBLIC SCHOOL RESPONSES TO STUDENT CONCUSSIONS
}

\author{
Perry A. Zirkel \\ Lehigh University
}

\begin{abstract}
This article provides an up-to-date and comprehensive canvassing of the judicial case law concerning the responses to students with concussions in the public school context. The two categories of court decisions are (a) those concerning continued participation in interscholastic athletics, referred to under the rubric of "return to play" and (b) those concerning the legal obligations in facilitating the continued educational progress of the student, referred to under the rubric of "return to school." The case law in the first category primarily addresses state common law claims of negligence and federal constitutional claims under the Fourteenth Amendment due process clause. The court decisions in the second category primarily address the successive issues of child find, eligibility, and "free appropriate public education" (including but not necessarily limited to accommodations) under Section 504 of the Rehabilitation Act and the Individuals with Disabilities Education Act. The outcomes of the court decisions thus far have been largely in favor of the district defendants, but the case law is far from crystallized and complete.
\end{abstract}

Keywords: concussion; law; IDEA; accommodations 


\section{Introduction}

Due to increasing awareness of chronic traumatic encephalopathy among former NFL players, legal analysts have referred to a "concussion crisis" (e.g., Greer, 2014). The recognition of concussions and the public schools' appropriate responses to them have been more belated in extracurricular athletics and, even more so, in the curricular program. For the return to school, the framework of the public school's legal obligations include, but is not limited to, Section 504 of the Rehabilitation Act and its fraternal twin in this context, the Americans with Disabilities Act (ADA), as well as the Individuals with Disabilities Education Act (IDEA).

The special education literature entirely lacks coverage of the legal issues arising when students sustain concussions. The literature in other fields focuses on the role of specialized personnel, such as school psychologists (e.g., Lewandowski \& Rieger, 2009), school nurses (e.g., Weber, Welch, Parsons, \& McLeod, 2015), athletic trainers (e.g., McGrath, 2010), pediatricians (e.g., Halstead et al., 2013), and statewide teams (e.g., Gioia, Glang, Hooper, \& Brown, in press). Law-related sources primarily focus on the NFL or intercollegiate sports (e.g., Bonds, Edwards, Spradley, \& Phillips, 2015; Gould, 2012). The few sources specific to legal developments within the $\mathrm{K}-12$ context have focused on state return-to-play legislation, not litigation (e.g., Johnson, 2012; Toporek, 2013). The limited exception (Zirkel \& Brown, 2014) provided only a small sampling of the pertinent court decisions within a broader overview of the various legal developments and school nursing recommendations concerning K-12 students with concussions.

The purpose of this article is to provide a comprehensive and up-to-canvassing of the court decisions specific to public school obligations in response to students with concussions. The summarization includes a reasonable representation of the legal nuances of this case law. The alternative of avoiding the evolving contours and masking the complex nature of the applicable case law tends too much toward paternal over-simplification and subjective advocacy.

The coverage is based on a search for all, not just a sampling, of the generally available and specifically relevant court decisions. Given the factual and legal variance under the rubric of concussions in relation to schools, the boundaries of coverage need to be clearly demarcated. First, the scope is limited to two categories of cases: (a) those specific to the failure to respond appropriately to concussions on the playing field, referred to generally under the "return to play" rubric and (b) those specific to the separable failure to respond appropriately to concussions in school, referred to generally under the "return to school" rubric. In these cases, the concussion is the direct stimulus for the litigation. Consequently, the many court decisions where some other action or inaction is the primary part of the case and the concussion is limited to the measure of the relief, or damages, are excluded (e.g., Hinterberger v. Iroquois School District, 2013; K.R.S. v. Bedford Community School District, 2015; Lamb v. Shaker Regional School District, 2015). Second, the coverage is limited to the $\mathrm{K}-12$ public school context, thus not extending to private school cases (e.g., Dugan v. Thayer Academy, 2015) or those in postsecondary education (e.g., In re NCAA Student-Athlete Concussion Litigation, 2013). Third, the scope is limited to court decisions, thus not extending to the administrative rulings of the U.S. Department of Education's Office for Civil Rights under Section 504 and the ADA (e.g., Albuquerque Public Schools, 2005), the state education agencies' corresponding complaint investigation process under the IDEA (e.g., El Paso County School District No. 3, 2012), and the impartial hearing process under the 
IDEA (e.g., Mars Area School District, 2015).

In contrast, the scope is not limited chronologically or jurisdictionally. However, based on a relatively exhaustive search of the two general legal databases, Westlaw and LEXIS, and the student disability database, LRP's Specialedconnection $®$, the pertinent court decisions have been all within the past 12 years, with the majority in Pennsylvania courts.

\section{Return to Play: Continued Participation in Interscholastic Athletics}

The extent and nature of the response in interscholastic athletics is often referred to under the rubric of "return to play," which concerns the student-athlete's continued participation after exhibiting the symptoms of a concussion. As arrayed in chronological order in Table 1, the litigation to date, which has been a lengthening and widening line of cases, largely consists of liability lawsuits against coaches and their school district employers, primarily premised on negligence and/or the Fourteenth Amendment's due process clause. Negligence is a matter of state common law, requiring the failure, by omission or commission, to meet the standard of care of due diligence, that causes injury. The increasing availability of concussion protocols in state law and interscholastic athletic association rules facilitates the operational meaning of the applicable standard of care. However, the retention of governmental and official immunity in several states, which bars negligence liability of government agencies, such as public schools, and their employees, has the opposite, inhibiting effect. Due to this varying pattern of immunity from state to state, the plaintiffs, who are parents suing on behalf of the injured student-athletes, have additionally or alternatively asserted liability claims based on the federal civil rights law, specifically public schools' action that creates a danger to the bodily integrity, or physical safety, of the students in their charge. The added incentives for these federal civil rights claims are the availability of attorneys' fees and generally higher liability verdicts if the plaintiffs prevail.

Finally, the available court opinions do not tell the complete story. First, although electronic databases "publish" an increasing proportion of court opinions, courts do not issue formal opinions in many cases, particularly at the trial level and more so for the state than federal courts. Second, the pertinent opinions that are published are often in response to pretrial motions for dismissal, which is in response to the initial complaint, or summary judgment, which is after sworn statements obtained from potential witnesses via the so-called "discovery" process. For such motions, courts assume that the allegations, interpreted in the light most favorable to the plaintiff parents (because the defendants' dismissal or summary judgment motion would deprive the plaintiffs of their day in court), are the facts. In cases where the court's decision is to deny the motion of the defendant coaches and/or district, the plaintiff parents have obtained only an inconclusive victory; they have "won" the opportunity to move ahead with further judicial proceedings, which may be in favor of either party and which may well not be published, or extra-judicial resolution, which would be either abandonment or settlement, depending on various factors, including the transaction costs, outcomes odds, and resources/resilience for each side. 
Table 1

Overview of Return to Play Cases

\begin{tabular}{|c|c|c|c|c|c|}
\hline Case Name & $\begin{array}{l}\text { Jurisdiction/ } \\
\text { Court }\end{array}$ & Year & Claim(s) & Outcome(s) & Rationale \\
\hline $\begin{array}{l}\text { Cerny v. Cedar Bluffs } \\
\text { Junior/Senior Pub. Sch. }\end{array}$ & Neb. S. Ct. & 2004 & negligence & for district defendants & $\begin{array}{l}\text { met duty of reasonable } \\
\text { care }\end{array}$ \\
\hline Yatsko v. Berezwick & $\begin{array}{l}\text { federal trial } \\
\text { ct. in Pa. }\end{array}$ & 2008 & $\begin{array}{l}14^{\text {th }} \text { Amendment } \\
\text { subst. due process }\end{array}$ & for district defendants & not shocking \\
\hline $\begin{array}{l}\text { Alt v. Shirey } \\
\text { [see also Table 2] }\end{array}$ & $\begin{array}{l}\text { federal trial } \\
\text { ct. in Pa. }\end{array}$ & 2012 & $\begin{array}{l}14^{\text {th }} \text { Amendment } \\
\text { subst. due process }\end{array}$ & $\begin{array}{l}\text { inconclusive (for } \\
\text { plaintiff parents) }\end{array}$ & $\begin{array}{l}\text { sufficient for further } \\
\text { proceedings }\end{array}$ \\
\hline Lavella v. Stockhausen & $\begin{array}{l}\text { federal trial } \\
\text { ct. in } \mathrm{Pa} \text {. }\end{array}$ & 2013 & $\begin{array}{l}14^{\text {th }} \text { Amendment } \\
\text { subst. due process }\end{array}$ & for district defendants & not shocking \\
\hline $\begin{array}{l}\text { Mann v. Palmerton Area } \\
\text { Sch. Dist. }\end{array}$ & $\begin{array}{l}\text { federal trial } \\
\text { ct. in } \mathrm{Pa} \text {. }\end{array}$ & 2014 & $\begin{array}{l}14^{\text {th }} \text { Amendment } \\
\text { subst. due process }\end{array}$ & $\begin{array}{l}\text { inconclusive (for } \\
\text { plaintiff parents) }\end{array}$ & $\begin{array}{l}\text { sufficient for further } \\
\text { proceedings }\end{array}$ \\
\hline $\begin{array}{l}\text { Ripple v. Marble Falls } \\
\text { Indep. Sch. Dist. } \\
\text { [see also Table 2] }\end{array}$ & $\begin{array}{l}\text { federal trial } \\
\text { ct. in Texas }\end{array}$ & 2015 & $\begin{array}{l}\text { Section } 504 \text { and } \\
\text { the ADA }\end{array}$ & for district defendants & $\begin{array}{l}\text { not gross mis- } \\
\text { judgment or bad faith }\end{array}$ \\
\hline $\begin{array}{l}\text { Croce v. W. Chester } \\
\text { Area Sch. Dist. }\end{array}$ & $\begin{array}{l}\text { federal trial } \\
\text { ct. in } \mathrm{Pa} \text {. }\end{array}$ & 2015 & $\begin{array}{l}14^{\text {th }} \text { Amendment } \\
\text { subst. due process }\end{array}$ & for district defendants & $\begin{array}{l}\text { not deliberate } \\
\text { indifference }\end{array}$ \\
\hline \multirow{2}{*}{$\begin{array}{l}\text { M.U. v. Downingtown } \\
\text { High Sch. E. }\end{array}$} & \multirow{2}{*}{$\begin{array}{l}\text { federal trial } \\
\text { ct. in } \mathrm{Pa} \text {. }\end{array}$} & \multirow{2}{*}{2015} & $\begin{array}{l}14^{\text {th }} \text { Amendment } \\
\text { subst. due process }\end{array}$ & for district defendants & not shocking \\
\hline & & & negligence & for district defendants & $\begin{array}{l}\text { governmental } \\
\text { immunity }\end{array}$ \\
\hline $\begin{array}{l}\text { J.M. v. Huntington } \\
\text { Beach High School Dist. }\end{array}$ & Cal. Ct. App. & 2015 & negligence & for district defendants & $\begin{array}{l}\text { statute of limitations } \\
\text { (i.e., late filing) }\end{array}$ \\
\hline
\end{tabular}




\section{State Common Law: Negligence}

The available, pertinent case law concerning negligence claims in return to play cases is notably limited to three court decisions. Nevertheless, these cases illustrate the outcome-determinative significance of the standard of care, which is becoming increasingly rigorous, and the immunity defense, which varies from state to state.

In the first case, governmental immunity was not at issue, presumably because its limited extent in Nebraska did not apply to return to play cases. In this case, the coach and assistant coach allowed a high school football player to reenter the game and participate in practice after sustaining a concussion during a game in 1995, which resulted in further injuries. In a decision at the end of nine years of litigation, Nebraska's highest court affirmed the trial court's decision that the coach and assistant coach had met the applicable standard of care (Cerny v. Cedar Bluffs Junior/Senior Public School, 2004). The standard at that time was the conduct required of a reasonably prudent person holding a Nebraska teaching certificate with a coaching endorsement: (a) to be familiar with the features of a concussion; (b) to evaluate the player who appeared to have suffered a head injury for the symptoms of a concussion; (c) to repeat the evaluation at intervals before the player would be permitted to reenter the game; and (d) to determine, based upon the evaluation, the seriousness of the injury and whether it was appropriate to let the player reenter the game or to remove the player from all contact pending a medical examination. In the increasing number of states that currently have more rigorous standards, such as specified testing and clearance from a trainer or physician, the same facts could have a different judicial outcome.

However, as mentioned above, several states have retained to a varying extent governmental and official immunity to negligence suits, thus providing a possible defense for school districts and their employees (Maher, Price, \& Zirkel, 2011). For example, Pennsylvania provides such immunity with exceptions that do not apply to these concussion-related negligence suits. As a result, the court in M.U. v. Downingtown High School East (2015) dismissed the negligence claims against the coach of the girls' varsity soccer team and the school district. The plaintiff parents alleged that the coach failed to take one of the players out of a preseason scrimmage after she had fallen down crying from a head-on collision with another player and that, subsequently in the scrimmage, she experienced other collisions and headed the ball several times, leading to the diagnosis the next day of traumatic brain injury. Because the plaintiffs' negligence claim did not fit within any of the limited exceptions, such as school vehicles or school real estate, it did not survive this early pretrial motion.

As a similar fatal threshold procedural issue, a California appeals court upheld, for lack of timely filing, the negligence claim on behalf of a high school football player whom the coach allegedly allowed to continue to participate after exhibiting concussion symptoms (J.M. v. Huntington Beach High School District, 2015). More specifically, the court interpreted the state's Government Claims Act six-month limitations period for filing suit as strictly mandatory, thus disposing of the suit without any further proceedings as to the merits of the claim. This case is currently on appeal to California's highest court. 


\section{Federal Civil Rights Law}

Likely attributable to the state's applicable immunity, its emphasis on interscholastic athletics, and its relatively high rate of education litigation, Pennsylvania has been the scene of several return to play cases where the plaintiff parents filed federal civil rights claims under Fourteenth Amendment substantive due process. All the available decisions with written opinions have been at the pretrial stage, in response to motions for dismissal or summary judgment. In the majority of these pertinent, published cases, the courts have ruled in favor of the defendants, but in a notable minority the courts preserved the claim for further judicial proceedings. The analysis and outcomes reveal the relatively consistent successive standards for the individual and institutional defendants. In short, the threshold hurdle for the plaintiff parents is to show they have fulfilled the technical adjudicative prerequisites, such as timely filing of the suit under the state of limitations application to their claim(s). Next are the standards for deciding the merits of their claim(s). For these Fourteenth Amendment substantive due process claims against the defendant coaches, the plaintiff parents must show that the conduct was clearly more flagrant than the lackof-due-diligence standard for negligence. Specifically, they must show that the coach's conduct represented at least deliberate indifference to the student's safety, which is the bottom level of a zone of behavior that is shocking to the conscience of society. This standard obviously poses a rather steep slope to establish liability. Posing an added hurdle, for liability of the defendant districts, the plaintiff parents must show ratification in terms of a policy, practice, or custom that causally connects to the deliberately indifferent coaches' conduct.

The majority of the seven federal civil rights claims in Table 1, including the one based on Section 504 and the ADA, were conclusively in favor of the district defendants. The remaining two decisions were inconclusively in favor of the plaintiff parents, because in each of these two cases the court preserved the claim for further judicial proceedings. The difference in outcomes between these two groups of cases was largely a matter of the foundational facts, although other factors, such as the efficacy of the attorneys and the perceptions of the individual judge, may have played a contributing role.

Majority rulings. In Yatsko v. Berezwick (2008), the earliest decision in this lengthening line of cases conclusively for the defendants, the allegations, which serve as facts for a motion for dismissal, were as follows: (a) in a varsity girls basketball game, after the plaintiff parents' daughter experienced concussive symptoms as the result of a head-to-head collision with an opposing player, the coaches did not take her to the trainer and only kept her on the bench because the score was lopsided; (b) in a game two days later, after the student informed the coaches that her headache, nausea, and weakness had continued without abatement, they told her that because she was the tallest player on the team she needed to play but she could signal them if necessary; (c) her nausea, shaking, and unsteadiness increased at the end of the game, and she collapsed in the locker room; (d) at the hospital that night, the head coach admitted to the parent that he "had made the wrong call" in allowing her to play; (e) the state interscholastic association handbook advised coaches not to allow students who suffered concussions to return to play until the full recovered as attested by a physician; and (f) the student subsequently graduated but dropped out of college due to serious brain injuries. The parents' federal civil rights claim was premised on the due process clause of the Fourteenth Amendment, asserting liability based on the recognized but limited theory of state-created danger. The court granted the coaches' motion 
to dismiss the claim, concluding that it could have been viable in terms of negligence but was not sufficiently egregious to meet the settled standard of conscience-shocking governmental conduct. Further, the interscholastic athletic association's rules merely strengthened the viability of negligence but did not change the substantive due process analysis. Given the outcome for the individual defendants, the court also dismissed the derivative federal claim against the district.

Next, in Lavella v. Stockhausen (2013), the parents of a high school cheerleader filed a federal civil right suit against the cheerleading coach premised on the state-created danger theory of Fourteenth Amendment substantive due process. According to their allegations, the coach had the student skip the district concussion testing and engage in dangerous stunting moves despite knowledge that she had sustained separate concussions while participating in other stunts one week and two weeks earlier. Observing that the student's physician had cleared her for returning to cheerleading activity without restriction, the federal district court granted the defendant's motion to dismiss the suit for failure to show the requisite shocking-to-the-conscience level of conduct.

More recently, in the aforementioned Pennsylvania decision in M.U. v. Downingtown High School East (2015), the federal court similarly granted both the coaches' and district's motions to the parents' Fourteenth Amendment substantive due process state-created danger claims. For the civil rights claim against the coach, the court concluded that the plaintiff parents had failed to allege facts sufficient to show that he had engaged in "conduct that shocks the conscience, even at the lowest end of the culpability continuum-deliberate indifference" (p. 624). First, not finding her crying sufficient alone, the court pointed out that she had not informed the coach or exhibited any signs of a concussion. Second, the court reasoned that the then recent Pennsylvania youth sports safety statute, which prescribed protocols for suspected concussions of student athletes, could be relevant to a claim of negligence but was not relevant to the federal statecreated danger claim. Third, the court observed that the plaintiffs' claims against the coach were all premised on his inaction, not action. Similarly allowing the plaintiffs the opportunity to amend their complaint, the court dismissed their complaint against the district for failure to show a sufficient connection between its policies, practices, or custom with the alleged constitutional violation.

Most recently, in a similar result in terms of the district defendant, a federal court in another Pennsylvania case rejected liability based on the same federal civil rights theory in a case where a high school junior varsity football player allegedly incurred injuries after being allowed to reenter the game after sustaining a concussion (Croce v. West Chester Area School District, 2015). Disposing of the claim prior to a trial, the court concluded that the parents had failed to show that the district's policy, practice, or custom caused his alleged injuries, or that the district had acted with deliberate indifference to his rights. Rather, the pretrial documents revealed that the district followed accepted concussion protocols, including baseline testing at the start of the season and an evaluation by the athletic trainer as a precondition to resuming participation.

Minority rulings. In contrast, based largely on different circumstances, two intervening Pennsylvania cases had the opposite rulings in response to the defendants' pretrial motions. This minority view, although notable in relative number, is only partially opposite of the majority rulings because the outcome was only inconclusively in favor of the plaintiffs. First, in Alt $v$. 
Shirey (2012), the court denied the individual and district defendants' motion to dismiss the Fourteenth Amendment substantive due process claim based on state-created danger because the allegations were that the football coaches failed to provide any cognitive testing to the player, a tenth grader, after he experienced visibly disorienting hits to his head in two previous games. Upon a severe helmet-to-helmet collision that resulted in notable concussive symptoms, the coaches not only allowed, but ordered, the student to reenter the game without any cognitive testing, additionally directing him to deliver a substantial hit to the opposing player. As a result of the original and subsequent collisions, the student had substantial traumatic brain injuries. The court concluded that these allegations, if proven, would establish the requisite deliberate indifference to substantial risk of harm on the part of the defendant coaches. The court further ruled that the allegations of the student's visible injuries in open view at three separate games without appropriate protocols were sufficient to establish possible liability of the defendant district based on custom or practice.

Second, the federal court in another Pennsylvania case denied the motion to dismiss the Fourteenth Amendment due process claim on behalf of a high school football player, who suffered a traumatic brain injury upon a second collision after the coaches allegedly, without any concussion testing, directed him to continue to practice after the first dizzying hit to his head (Mann v. Palmerton Area School District, 2014). For the individual defendants, who were the coaches, the deliberate indifference, or shocking disregard for the student's safety, was the alleged direction to return to play despite untested symptoms of a head injury - an act of commission, not omission. For the district defendant, unlike the Croce case, the plaintiff parents had sufficiently shown the causal connection of the district's policy or custom to this deliberate indifference by specifically alleging its failures to train coaches on safety protocol and indicators of a concussion; to have proper procedures in place to treat concussions and other head injuries; and to instruct student athletes on the causes, symptoms, and dangers of traumatic brain injuries.

Finally, in a marginally pertinent Texas case that relied on Section 504 rather than the Fourteenth Amendment and that based the athletics-context claim on various safety-related acts or omissions, including but extending beyond concussions, the court based its dismissal on the lack of bad faith or gross misjudgment, which precedent has established as a prerequisite for liability under Section 504 and/or the ADA (Ripple v. Marble Falls Independent School District, 2015). For his football-related concussions, the court concluded:

According to [the student], his doctors cleared him annually to play football. The coaching staff never sent [him] back onto the field during the game when he sustained the injuries he complained of. The only concussion that [he] informed the athletic team about was the one he sustained after [one] game; he avoided reporting and seeking treatment for his concussive symptoms thereafter in an attempt to remain competitive for college scholarship. (p. 691)

\section{Return to School: Alleged Inappropriate Responses}

One marginally relevant court decision serves as a bridge between the return-to-play and returnto-school cases. More specifically, in this case a school district expelled a high school football player for assaulting two coaches on the sidelines after he sustained a concussion in the game. 
Thus, the claim arose in the context of the play of the game but its thrust fit better, although marginally, in the return to school, because the student's parents were challenging the expulsion. The court summarily rejected their Fourteenth Amendment equal protection claim that two other similarly situated students had received much more lenient disciplinary treatment, thus purportedly proving illegal discrimination (Davis v. Houston County Board of Education, 2008). The court's reasoning was that, even assuming for the sake of argument that the concussion affected his behavior, his individual circumstances were notably different from those of the other two students, thus justifying the differential treatment.

\section{Eligibility and Accommodations/Services}

For responses to concussions within the core context of schooling, in contrast with interscholastic athletics, the plaintiffs were parents of students whose concussions may or may not have occurred in school sports. Moreover, they have additional avenues for their litigation claims beyond the Fourteenth Amendment and negligence. More specifically, the pair of disability discrimination laws - Section 504 and the ADA - and the narrower but more detailed coverage of the IDEA, provide the foundation for claims based on (a) "child find," or the obligation to conduct an appropriate evaluation upon reasonable suspicion of possible eligibility; (b) identification, or eligibility; and (c) "free appropriate public education" (FAPE). Although the regulations and case law under both Section 504 and the IDEA clearly establish all of these obligations (e.g., Zirkel, 2012), a major difference is their respective definitions of disability. For the IDEA, eligibility requires not only meeting the criteria of one or more specified classifications, such as traumatic brain injury or other health impairment, but also a resulting need for special education services. In contrast, Section 504 and its sister statute, the ADA, have a broader scope of eligibility, which is centered on physical or mental impairments that substantially limit one or more major life activities, including but not limited to learning. As explained elsewhere in more detail (Zirkel, 2015), although the ADA amendments of 2008 liberalized the standards for eligibility, duration is often still the key criterion as to whether one or more concussions alone qualify a student for eligibility under Section 504.

As displayed in chronological order in Table 2, the pertinent litigation to date in the return-toschool context is increasing but still relatively fluid. One of the reasons is the procedural requirement in the IDEA that allows alternative avenues for claims that overlap with the coverage of the IDEA but that requires, as a procedural prerequisite, that the plaintiff parents exhaust the available administrative mechanism of the impartial hearing under the IDEA before proceeding to court. Another reason is the statute of limitations, or the prescribed period for initiating proceedings, under the identified basis for the claim. Several of the cases have not reached the merits, or the central issues, due to these litigation prerequisites.

Statute of limitations. A pertinent case that illustrates the effect of this timely-filing requirement, along with the additional prerequisite of subject matter jurisdiction, is Moyer $v$. Long Beach Unified School District (2013). In this case, after a series of concussions, including one during a high school football game, a student began to experience memory loss and engage in unusual behavior, such as eating the bark from trees. The district provided a 504 plan but never conducted an IDEA evaluation for him. The parents subsequently enrolled him in a residential school and then a brain institute. They filed for a due process hearing when he was 20 
Table 2

Overview of Return to School Cases

\begin{tabular}{|c|c|c|c|c|c|}
\hline Case Name & $\begin{array}{c}\text { Jurisdiction/ } \\
\text { Court }\end{array}$ & Year & Claim(s) & Outcome(s) & Rationale \\
\hline $\begin{array}{l}\text { Davis v. Houston Cnty. } \\
\text { Bd. of Educ. }\end{array}$ & $\begin{array}{l}\text { federal trial } \\
\text { ct. in Ala. }\end{array}$ & 2008 & $\begin{array}{l}14^{\text {th }} \text { Amendment } \\
\text { equal protection }\end{array}$ & for district defendants & not discriminatory \\
\hline \multirow{3}{*}{$\begin{array}{l}\text { Alt v. Shirey } \\
{[\text { see also Table 1] }}\end{array}$} & \multirow{3}{*}{$\begin{array}{l}\text { federal trial } \\
\text { ct. in Pa. }\end{array}$} & \multirow{3}{*}{2012} & $\begin{array}{l}14^{\text {th }} \text { Amendment } \\
\text { proc. due process }\end{array}$ & $\begin{array}{l}\text { inconclusive (for } \\
\text { plaintiff parents) }\end{array}$ & $\begin{array}{l}\text { sufficient for further } \\
\text { proceedings }\end{array}$ \\
\hline & & & $\begin{array}{l}14^{\text {th }} \text { Amendment } \\
\text { equal protection }\end{array}$ & for district defendants & lack of factual fit \\
\hline & & & $\begin{array}{l}\text { Section } 504 \text { and } \\
\text { the ADA }\end{array}$ & $\begin{array}{l}\text { inconclusive (for } \\
\text { plaintiff parents) }\end{array}$ & $\begin{array}{l}\text { sufficient for further } \\
\text { proceedings }\end{array}$ \\
\hline $\begin{array}{l}\text { Moyer v. Long Beach } \\
\text { Unified School District }\end{array}$ & $\begin{array}{l}\text { federal trial } \\
\text { ct. in Cal. }\end{array}$ & 2013 & IDEA & for district defendants & $\begin{array}{l}\text { statute of limitations } \\
\text { (i.e., late filing) }\end{array}$ \\
\hline \multirow{2}{*}{ Ortega v. Roulhac } & \multirow{2}{*}{$\begin{array}{l}\text { federal trial } \\
\text { ct. in Pa. }\end{array}$} & \multirow{2}{*}{2015} & negligence + & for district defendants & $\begin{array}{l}\text { governmental } \\
\text { immunity }\end{array}$ \\
\hline & & & $\begin{array}{l}14^{\text {th }} \text { Amendment } \\
\text { subst. due process }\end{array}$ & for district defendants & $\begin{array}{l}\text { insufficient (w. limited } \\
\text { inconclusive except.) }\end{array}$ \\
\hline $\begin{array}{l}\text { Ripple v. Marble Falls } \\
\text { Indep. Sch. Dist. } \\
\text { [see also Table 1] }\end{array}$ & $\begin{array}{l}\text { federal trial } \\
\text { ct. in Texas }\end{array}$ & 2015 & $\begin{array}{l}\text { Section } 504 \text { and } \\
\text { the ADA }\end{array}$ & $\begin{array}{l}\text { inconclusive (for } \\
\text { district defendants) }\end{array}$ & $\begin{array}{l}\text { exhaustion (i.e., } \\
\text { failure to go first to } \\
\text { impartial hearing) }\end{array}$ \\
\hline $\begin{array}{l}\text { Wellman v. Butler Area } \\
\text { Sch. Dist. }\end{array}$ & $\begin{array}{l}\text { federal trial } \\
\text { ct. in } \mathrm{Pa} \text {. }\end{array}$ & 2015 & Section 504 & $\begin{array}{l}\text { inconclusive (for } \\
\text { district defendants) }\end{array}$ & exhaustion \\
\hline $\begin{array}{l}\text { J.K. v. New Brighton } \\
\text { Area Sch. Dist. }\end{array}$ & $\begin{array}{l}\text { federal trial } \\
\text { ct. in } \mathrm{Pa} \text {. }\end{array}$ & 2015 & $\begin{array}{l}\text { Section } 504 \text { and } \\
\text { the ADA }\end{array}$ & $\begin{array}{l}\text { inconclusive (for } \\
\text { district defendants) }\end{array}$ & exhaustion \\
\hline $\begin{array}{l}\text { Perrin v. Warrior Run } \\
\text { Sch. Dist. }\end{array}$ & $\begin{array}{l}\text { federal trial } \\
\text { ct. in } \mathrm{Pa} \text {. }\end{array}$ & 2015 & IDEA & for district defendants & $\begin{array}{l}\text { appropriate evaluation } \\
\text { and not eligible }\end{array}$ \\
\hline $\begin{array}{l}\text { Berry v. RSU } 13 \text { Sch. } \\
\text { Bd. }\end{array}$ & $\begin{array}{l}\text { federal trial } \\
\text { ct. in Me. }\end{array}$ & 2016 & $\begin{array}{l}\text { 14th Amendment } \\
\text { subst. due process }\end{array}$ & for district defendants & not shocking \\
\hline
\end{tabular}


years old, claiming an IDEA child-find violation that started at age 16. The hearing officer ruled, and on appeal the federal district court affirmed, that the statute of limitations precluded the claims for the first two years and that California law, which only allows services to the $19^{\text {th }}$ birthday, precluded the claims for the last two years. Thus, the parent's claim fell short of reaching the merits.

Exhaustion. In the aforementioned Texas case in Ripple v. Marble Falls Independent School District (2015), the federal court dismissed without prejudice, i.e., allowing possible return to court, the plaintiff parents' Section 504/ADA claims specific to the return-to-school context. These two claims were, (a) child find, which concerns the requirement to evaluate the child for possible eligibility under the Section 504/ADA definition of disability; and (b) failure to provide the requisite accommodations and services under Section 504/ADA. The reason was the provision of the IDEA that conditions corresponding claims under other avenues, such as Section 504 and/or the ADA, on exhausting its impartial hearing mechanism.

In Wellman v. Butler Area School District (2015), a federal district court in Pennsylvania dismissed the parents' money damages claim under Section 504 and the ADA for failure to exhaust the administrative remedies under the IDEA. In this case, the factual foundation was different from J.K. in two respects: (a) the student's concussions were at school activities, first in a gym class flag football game and/or football practice on the same day and subsequently at a football game, when the coach allowed him to work on the sidelines upon not having the clearance to play and one of the players on the field accidentally collided with him; and (b) the parents filed for a hearing under the IDEA but entered into a settlement agreement with the district prior to the hearing. Nevertheless, the court held that based on the applicable strengthened precedent in the Third Circuit, which includes Pennsylvania, exhaustion depends on the nature of the claim, which here concerned identification and services under the IDEA, not the nature of the relief, which was a remedy not available under the IDEA - money damages. Moreover, the court cited various decisions that supported the view that settlement agreements do not suffice for purposes of the exhaustion requirement because they do not provide a fully developed factual record.

Similarly, in another Pennsylvania case where a concussion was in addition to ADHD and where the Section 504 claim focused on inadequate accommodations, the court similarly dismissed the case without prejudice (J.K. v. New Brighton Area School District, 2015). The reason, again, was the exhaustion requirement of the IDEA; the parents had not initiated and completed a due process hearing.

The merits. In contrast, in another Pennsylvania case, Perrin v. Warrior Run School District (2015), the plaintiff parents fulfilled the IDEA's exhaustion requirement of an impartial hearing before proceeding to court. More specifically, the parents first requested an evaluation for IDEA and, alternatively, Section 504 eligibility after their tenth grader had experienced multiple concussions - one three years earlier in a soccer game, a second one early in his tenth-grade year upon exiting gym class, and a third three months later during gym class. The district duly conducted the evaluation, concluding that although the concussions resulted in limitations, they were not sufficient to meet the applicable standards for eligibility under either the IDEA or Section 504. Not satisfied, the parents requested an independent educational evaluation (IEE) at 
public expense. In response, the district issued a refusal and filed for an impartial hearing under the IDEA. After conducting a hearing, the hearing officer ruled that the district's evaluation was appropriate, thus denying the requested IEE at district expense. During the eleventh grade, based on neurological recommendations from the student's physician, the district made arrangements for partial cyber schooling and consultation with a state concussion-related technical assistance team. In a second decision, the hearing officer ruled that the student did not need special education under the IDEA and was not limited in a major life activity, such as learning, as required for Section 504 eligibility.

Upon the parents' appeal of both hearing officers' decisions, the court in Perrin ruled in favor of the district. First, the court concluded that the district's evaluation was appropriate, pointing out that its obligation was to consider, not necessarily adopt, the opinion of the student's physician and neuropsychologist. Second, the court rejected the parents' "child find" claim under the IDEA, concluding that the district conducted the evaluation within a reasonable time after having knowledge of the student's two concussions in the first semester of tenth grade. Third, the court upheld the determination that the student did not qualify for eligibility under the IDEA or, without clearly separate reasoning, Section 504.

In another recent decision in Pennsylvania (Ortega v. Roulhac, 2015), a high school assistant principal in the Philadelphia school system caused the concussion and subsequent post-traumatic concussive syndrome, in a confrontation with a recalcitrant student, allegedly punching him in the face, grabbing him, and slamming him into file cabinets. Although the assistant principal was named as one of the defendants in the suit and apparently separately faced termination proceedings, the court's opinion was largely limited to the motion for dismissal filed by the district and its other, higher administrators named as the other defendants. The plaintiff parents' claims separately targeted the initial, physical abuse, which was on November 2, 2012, and the subsequent alleged inadequate response upon the student's return to school. More specifically, the allegations were that the student's physicians did not allow him to return to school until a month later due to extensive orthopedic, neurological, psychiatric, and ophthalmological injuries, and for the rest of the school year the district failed to provide him with the requisite accommodations and services, including but not limited to an evaluation and services under Section 504 or the IDEA, for the rest of the school year.

First, specific to the assistant principal's alleged physical misconduct, the Ortega court dismissed the plaintiff parents' claims of negligence and breach of fiduciary duty based on the aforementioned applicable immunity in Pennsylvania. Similarly, the court dismissed the plaintiff's corresponding claims against the other administrators and the district based on Fourteenth Amendment due process. The reason was the lack of the requisite connection between the other administrators and the assistant principal's abusive conduct.

Second, specific to the alleged lack of adequate response upon re-entry, the Ortega court dismissed the claims, which were all predicated on Fourteenth Amendment substantive due process, without prejudice. More specifically, the court readily concluded that the plaintiffs had failed to show how the state-created danger theory, as applied to the return-to-play cases, extends to return-to-school cases, but allowed them to file an amended complaint for this missing connection. The plaintiffs face an uphill slope in moving from the semi-successful acts of alleged 
deliberate indifference on the playing field of contact sports to the classroom of adequate education. It would seem that the plaintiffs missed firing Section 504 and IDEA bullets in their shotgun pleading, although the Section 504 requirements for bad faith or gross misjudgment represent high hurdles similar to deliberate indifference and the IDEA does not provide the remedy of money damages.

In the most recent case, a federal district court in Maine similarly dismissed the plaintiff parent's constitutional claims. The parent, proceeding without an attorney, sought liability for various alleged school personnel acts and omissions before and after injuries, including a concussion, that her son sustained as a member of the school ski club (Berry v. RSU 13 School Board, 2016). The only return-to-school allegation was that the school refused to allow the student to use the disability entrance despite his medically authorized disability placard. To the unclear extent that this act was part of liability claim, which was based on Fourteenth Amendment substantive due process, the lack of sufficient severity in terms of the requisite conscience-shocking standard led to dismissal.

Providing partial contrast in terms of it outcomes, the above-mentioned Alt v. Shirey (2012) case extended beyond the coaches' return-to play conduct to the subsequent return-to-school stage. The plaintiff parents also alleged that during the rest of the fall semester, their son's symptoms worsened; the accommodations were negligible; his grades declined; in January, the principal suggested that he could improve the student's grades with a "shake of his magic wand"; the student was absent for most of the spring semester and, yet; his final grades were almost all A's, which was markedly higher than those before his injuries; and this pattern of poor attendance and manipulated grades continued until his graduation. As a result, the plaintiff parents claimed that the principal had violated (a) Fourteenth Amendment procedural due process in terms of the student's property right to public education, (b) Fourteenth Amendment equal protection in terms of accommodations comparable to those for students with disabilities, and (c) Section 504 and the ADA. The court denied dismissal of the procedural due process claim, reasoning that it was without precedent either way and merited further deliberation. The court also denied dismissal of the Section 504/ADA claim, concluding that the parents had provided sufficient basis for further proceedings to determine whether their son qualified under the definition of disability under this pair of statutes and whether the district had failed to provide the requisite accommodations. Conversely, the court dismissed the equal protection claim, reasoning that such special accommodations are a matter of such special statutes, not the Constitution.

\section{Conclusion}

Concussions of public school students are, as a legal matter, a concern, not a crisis. On the playing field and in the classroom, public schools should have policies and procedures in place to protect the physical safety and facilitate the educational progress of students reasonably suspected of having sustained one or more concussions. The primary reason, however, for effectuating these policies should be professional proactivity rather than legal liability.

On the playing field, the starting point is state laws, along with the interscholastic athletic association rules. However, in terms of potential lawsuits based on return to play or return to school, concerns about negligence liability need to include the contours of applicable 
governmental and official liability. The alternative of federal civil rights claims, premised primarily on Fourteenth Amendment substantive due process, poses a steep uphill slope for plaintiff parents in relation to the individual coaches and even a steeper one in relation to the deeper pocket of school districts. Thus, rather than be paralyzed with fear of liability, school officials should move beyond these liability issues to considerations of professional discretion and educational best practice.

Although the frequency of these cases is relatively limited and the conclusive outcomes have all been in favor of districts, these data warrant a couple of caveats. First, the cases are limited to those that are published in terms of the generally available databases, thus serving as only the visible tip of the proverbial iceberg. Second, five (31\%) of these sixteen decisions had at least one inconclusive ruling, thus serving as the basis for settlement, abandonment, or an unpublished verdict. Regardless of the ultimate outcome in these inconclusive cases, the costs for both the plaintiff parents and the defendant districts in terms of time, hostility, and attorneys' fees merit tempering mutual attention.

In sum, whether the student sustains the concussion in interscholastic sports or not, schools need to be well prepared to take affirmative actions to facilitate the student's return to school for the sake of educational progress as well as medical safety. First, proactive, almost automatic protocols should be in place for return to school, just like return to play. Second, depending on the severity and duration of the impairing effects of the concussion, Section 504 or the IDEA may apply, adding specific legal requirements in flowchart-like fashion from "child find" to eligibility to FAPE. Finally, individual health plans under state law or school policy should serve as the backup for extending the immediate and informal appropriate adjustments, to the extent necessary, for students not eligible for 504 plans or IEPs. Timeliness and effectiveness are the keys for the sake of not only the student's health and education but also the school's potential legal costs for the ponderous process of judicial decision making.

Conversely, parents who are considering litigation, whether for liability in the narrow sense of money damages or for other forms of relief, such as compensatory education, should consider not only the applicable substantive standards, such as deliberate indifference, but also the procedural prerequisites, such as the limitations period for timely filing and the possible applicability of the IDEA's exhaustion requirement. The case law is still not fully crystallized, for example, thus far lacking a federal appeals court decision. Nevertheless, wider and deeper awareness of the pertinent court decisions to date is one step toward creating timely and effective responses to student concussions.

\section{References}

Albuquerque (NM) Pub. Sch., 106 LRP 9766 (OCR Feb. 25, 2005).

Alt v. Shirey, 2012 WL 726579 (W.D. Pa. Feb. 7, 2012), adopted, 2012 WL 726593 (W.D. Pa. Mar. 1, 2012).

Berry v. RSU 13 Sch. Bd., 2016 WL 742901 (D. Me. Feb. 24, 2016). 
Bonds, G. B, Edwards, W. W., Spradley, B. D., \& Phillips, T. (2015). The impact of litigation, regulation, and legislation on sport concussion management. Sport Journal. http://dx.doi.org/10.17682/sportjournal/2015.011

Cerny v. Cedar Bluffs Junior/Senior Pub. Sch., 679 N.W.3d 198 (Neb. 2004).

Croce v. W. Chester Area Sch. Dist., 2015 WL 1565834 (E.D. Pa. Apr. 8, 2015).

Davis v. Houston Cnty. Bd. of Educ., 2008 WL 410619 (M.D. Ala. Feb. 13, 2008).

Dugan v. Thayer Acad., 32 Mass. L. Rptr. 657 (Super Ct. 2015).

El Paso Cnty. Sch. Dist. No. 3, 60 IDELR II 117 (Colo. SEA 2012).

Gioia, G. A., Glang, A. E., Hooper, S. R., \& Brown, B. E. (in press). Building statewide infrastructure for the academic support of students with traumatic brain injury. Journal of Head Trauma Rehabilitation. http://dx.doi.org/10.1097/htr.0000000000000205

Gould, W. B. (2012). Football, concussions, and preemption: The gridiron of National Football League litigation. Florida International University Law Review, 8, 55-69.

Greer, M. (2014). Concussion crisis: Regulating the NFL's concussions policy under the commerce clause. Hastings Constitutional Law Quarterly, 42, 187-211.

Halstead, M. E., McAvoy, K., Devore, C. D., Carl, R., Lee, M., \& Logan, K. (2013). Returning to learning following a concussion. Pediatrics, 132, 948-957. http://dx.doi.org/10.1542/peds.2013-2867

Hinterberger v. Iroquois Sch. Dist., 548 F. App'x 50 (3d Cir. 2013).

In re NCAA Student-Athlete Injury Litigation, 988 F. Supp. 2d 1373 (N.D. Ill. 2013).

J.K. v. New Brighton Area Sch. Dist., 2015 WL 5638029 (W.D. Pa. Sept. 24, 2015).

J.M. v. Huntington Beach High Sch. Dist., 193 Cal. Rptr. 3d 196 (Ct. App. 2015), rev. granted, 362 P.2d 431 (2015).

Johnson, L. S. (2012). Return to play guidelines cannot solve the football-related concussion problem. Journal of School Health, 82, 180-185. http://dx.doi.org/10.1111/j.1746$\underline{1561.2011 .00684 . \mathrm{x}}$

K.R.S. v. Bedford Cmty. Sch. Dist., 109 F. Supp. 3d 1060 (S.D. Iowa 2015).

Lamb v. Shaker Reg'1 Sch. Dist., 120 A.3d 919 (N.H. 2015).

Lavella v. Stockhausen, 2013 U.S. Dist. LEXIS 62428 (W.D. Pa. May 1, 2013). 
Lewandowski, L. J., \& Rieger, B. (2009). The role of the school psychologist in concussions. Journal of Applied Psychology, 25, 95-110. http://dx.doi.org/10.1080/15377900802484547

Maher, P. J., Price, K., \& Zirkel, P. A. (2010). Governmental and official immunity for school districts and their employees: Alive and well? Kansas Journal of Law and Public Policy, 19, 234-270.

Mann v. Palmerton Area Sch. Dist., 33 F. Supp. 3d 530 (E.D. Pa. 2014).

Mars Area Sch. Dist., 115 LRP 56455 (Pa. SEA Oct. 31, 2015).

McGrath, N. (2010). Supporting the student-athlete's return to the classroom after a sportsrelated concussion. Journal of Athletic Training, 45, 492-498. http://dx.doi.org/10.4085/1062-6050-45.5.492

Moyer v. Long Beach Unified Sch. Dist., 60 IDELR II 126 (C.D. Cal. 2013).

M.U. v. Downingtown High Sch. E., 103 F. Supp. 3d 612 (E.D. Pa. 2015).

Ortega v. Roulhac, 64 IDELR II 298 (E.D. Pa. 2015).

Perrin v. Warrior Run Sch. Dist., 66 IDELR đI 225 (M.D. Pa. 2015), adopted, 66 IDELR II 254 (M.D. Pa. 2015).

Ripple v. Marble Falls Indep. Sch. Dist., 99 F. Supp. 3d 662 (W.D. Tex. 2015).

Toporek, B. (2013, April 17). Youth-concussion law passes in Arkansas. Education Week, pp.4-5.

Weber, M. L., Welch, C. E., Parsons, J. T., \& McLeod, T. C. (2015). School nurses' familiarity and perceptions of academic accommodations for student-athletes following sportsrelated concussion. Journal of School Nursing, 31, 146-154. http://dx.doi.org/10.1177/1059840514540939

Wellman v. Butler Area Sch. Dist., 2015 WL 5156920 (W.D. Pa. Sept. 2, 2015).

Yatsko v. Berezwick, 2008 WL 2444503 (E.D. Pa. June 13, 2008).

Zirkel, P. A. (2012). A comprehensive comparison of the IDEA and Section 504/ADA. West's Education Law Reporter, 282, 767-784.

Zirkel, P. A. (2015). Are students with concussions qualified for 504 plans? West's Education Law Reporter, 311, 589-93.

Zirkel, P. A., \& Brown, B. E. (2014). K-12 students with concussions: A legal perspective. Journal of School Nursing, 31, 99-109. http://dx.doi.org/10.1177/1059840514521465

Authors' note: Address correspondence concerning this article to Perry A. Zirkel at College of Education, 111 Research Drive, Lehigh University, Bethlehem, PA 18015. 